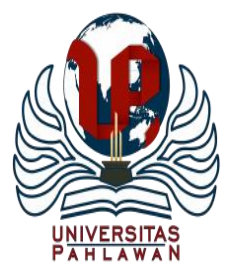

Edukatif : Jurnal Ilmu Pendidikan Volume 3 Nomor 5 Tahun 2021 Halm 2501 - 2512

EDUKATIF: JURNAL ILMU PENDIDIKAN

Research \& Learning in Education

https://edukatif.org/index.php/edukatif/index

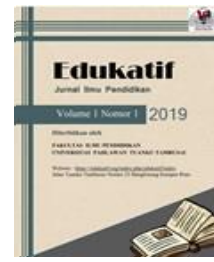

\title{
Pengaruh Tingkat Pendidikan, Pendapatan Orang Tua, Semangat Belajar, dan Fasilitas Belajar terhadap Prestasi Belajar Siswa di Masa Pandemi
}

\author{
Mochammad Vecky al Zuhry ${ }^{1 凶}$, Muhammad Abdul Ghofur ${ }^{2}$ \\ Universitas Negeri Surabaya, Indonesia ${ }^{1,2}$ \\ E-mail : mochammad.17080554077@ mhs.unesa.ac.id ${ }^{1}$ muhammadghofur@unesa.ac.id $^{2}$
}

\begin{abstract}
Abstrak
Tahun 2020 - sekarang pandemi Covid-19 juga belum usai. Penelitian berikut mempunyai tujuan guna mengatahui pengaruh tingkat pendapatan orangtua, semangat belajar, dan fasilitas belajar terhadap prestasi belajar. Strategi yang dipakai pada penelitian berikut menggunakan metodologi kuantitatif. Metode ini menggunakan probability sampling untuk menghasilkan 100 siswa. Pengumpulan data memakai teknik dokumentasi dan kuisioner. Hasil analisa dari uji t menyimpulkan jika tingkat pendidikan orang tua secara keseluruhan mempengaruhi prestasi belajar siswa, tingkat pendapatan orangtua tidak mempengaruhi prestasi belajar siswa, keinginan belajar mempengaruhi prestasi belajar siswa dan fasilitas belajar tidak mempengaruhi prestasi siswa. Siswa SMK tamsis Mojokerto kelas X diharapkan agar lebih mandiri, lebih percaya akan kemampuan yang dimiliki.
\end{abstract}

Kata Kunci: Tingkat pendapatan orangtua, tingkat pendidikan orangtua, semangat belajar, dan fasilitas belajar.

\begin{abstract}
The year 2020-now the Covid-19 pandemic is likewise not finished. This examination intends to decide the impact of guardians' pay level, excitement for learning, and learning offices on learning accomplishment. The system utilized in this examination utilizes a quantitative philosophy. This technique utilizes likelihood inspecting to create 100 understudies. Information assortment utilizes documentation and poll methods. The consequences of the investigation of the t test presumed that the degree of instruction of guardians all in all influences understudy accomplishment, the degree of parental pay doesn't influence understudy accomplishment, the longing to learn influences understudy accomplishment and learning offices don't influence understudy accomplishment. Students of SMK Tamsis Mojokerto class X are expected to be more independent, more confident in their abilities.
\end{abstract}

Keywords: Parents' income level, parents education level, enthusiasm for learning, and online learning facilities.

Copyright (c) 2021 Mochammad Vecky al Zuhry, Muhammad Abdul Ghofur

$\triangle$ Corresponding author

Email : mochammad.17080554077@mhs.unesa.ac.id

ISSN 2656-8063 (Media Cetak)

DOI $\quad$ : https://doi.org/10.31004/edukatif.v3i5.895

ISSN 2656-8071 (Media Online) 


\section{PENDAHULUAN}

Pandemi COVID-19 merupakan musibah yang mengakibatkan seluruh aktivitas masyarakat menjadi terbatas beserta ruang gerak berbagai aspek dibatasi, tanpa kecuali dalam aspek pendidikan. Alat yang digunakan dalam meningkatkan kecerdasan pengetahuan dan keahlian merupakan salah satu teknik pembelajaran di lingkungan sekolah (Prihatin, 2016). Selain alasan tersebut, sekolah merupakan tempat sekaligus kegiatan yang menyenangkan bagi siswa, karena mereka dapat melakukan interaksi antar individu di lingkungan sekolah tersebut. Selain itu, peningkatan keterampilan beserta kesadaran sosial siswa dapat didapatkan di sekolah dan sebagai sarana interaksi serta peningkatan kemampuan antara guru dan murid seperti intelegensi, keahlian, dan rasa kasih sayang mereka.

Prestasi belajar adalah pencapaian hasil oleh orang-orang ketika mereka telah merubah metode dalam belajar, baik di dalam suasana sekolah maupun di luar sekolah. Apa yang umumnya diantisipasi dari hasil belajar biasanya merupakan prestasi belajar yang maksimal. Meskipun demikian, dalam upaya mencapai hasil belajar yang baik, ternyata masihlah terdapat kendala serta prestasi yang belum ideal untuk diraih. Menurut (Slameto, 2010) prestasi belajar diberikan pengaruhnya oleh dua komponen, yakni komponen dalam serta luar siswa.

Menurut (Syah, 2010) terdapat dua faktor yang memberikan pengaruh pada prestasi belajar, yakni faktor dalam dan faktor luar. Faktor internal adalah variabel mental dan fisiologis siswa. Komponen mental meliputi perspektif, bakat, minat, pengetahuan, dan inspirasi, sedangkan faktor fisiologis seperti pendengaran, struktur tubuh, penglihatan, dll. Kemudian, pada saat itu faktor luar dibagi menjadi dua, khususnya faktor alam yang ramah dan faktor non-sosial. Yang dimaksud dengan komponen alam ramah adalah keluarga, sahabat, pengajar dan staf, dan lingkungan setempat. Sementara itu, faktor ekologi non-sosial seperti sains, inovasi, adat istiadat, fasilitas pembelajaran, ekspresi, dan lingkungan.

Pendidikan orang tua yang mempunyai keselarasan dengan pendapatan mereka, pendapatan yang tinggi secara tidak langsung akan lebih mudah dalam membiayai atau memfasilitasi pendidikan anaknya, seperti dalam menyekolahkan sang anak hingga ke jenjang pendidikan perguruan tinggi. Dalam lingkungan masyarakat, status ekonomi seseorang ditentukan melalui jenis pekerjaan yang sedang ditekuni. Semakin tinggi status kepemilikan pekerjaan seseorang, maka kebutuhan hidupnya dapat terpenuhi hingga ke tahap tersier (kebutuhan barang mewah). Pada dasarnya orangtua mempunyai pekerjaan berstatus tinggi akan mudah mendukung pendidikan serta fasilitas anaknya. Sedangkan orang tua siswa dengan jenis penghasilannya tergolong rendah, maka orang tua lebih merasa kesulitan dalam membiayai serta memfasilitasi segala keperluan dalam pendidikan anaknya

Semangat belajar siswa SMK tamsis Mojokerto kelas X sangat tinggi, bisa dilihat dari cara mereka tetap belajar meskipun dalam masa pandemic namun mereka tetap belajar dan berusaha meraih prestasi belajar yang baik. Motivasi belajar bersumber dari dalam individu, baik itu bersumber dari suruhan, ajakan, atau paksaan dari eksternal siswa sehingga siswa berkenan atau termotivasi untuk belajar. Sedangkan motivasi menurut (Gleitman, 2017:134) yaitu pemasok daya dalam suatu keiatan secara terarah. Jadi kesimpulannya bahwa motivasi merupakan ajakan kepada seseorang dalam melakukan sebuah tindakan dengan tujuan tertentu.

Fasilitas belajar merupakan suatu media atau sarana yang patut tersedia untuk kelancaran kegiatan belajar. Yaitu yang berarti kegiatan pembelajaran akan terlaksana dengan baik jika pembelajaran didorong oleh ketersediaan fasilitas yang memadai. Fasilitas belajar pada dunia pendidikan identik dengan fasilitas pendidikan. Sehingga dapat diartikan jika fasilitas pendidikan merupakan suatu upaya dalam mempermudah dan memperlancar kegiatan belajar mengajar oleh guru kepada murid agar pembelajaran bisa berjalan efektif, efisien, teratur, dan lancar baik hal tersebut diadakan secara langsung maupun tidak langsung atau berupa benda bergerak maupun tidak bergerak. 
Sekolah SMK Tamsis Mojokerto kelas X merupakan sekolah yang berada di Mojokerto, ketika saya melakukan PPL di lokasi kendala dalam belajar online ialah saya mendapati keluhan dari berbagai siswa untuk tidak melakukan pembelajaran online terlalu lama karena biaya kuota yang dikeluarkan nantinya sebab informasi dari guru bahwasannya ekonomi orang tua siswa kebanyakan menegah ke bawah. Penelitian ini sejalan dengan (Wirawan, 2017) dengan penelitiannya menyatakan jika pengaruh status sosial ekonomi orang tua mempengaruhi secara signifikan terhadap prestasi belajar.

Adapun penelitian yang dilakukan oleh (Manginsihi, 2013) dari hasil penelitiannya berdasarkan hipotesisnya yang menyatakan jika status sosial ekonomi keluarga terdapat pengaruh positif terhadap prestasi belajar siswa. Penelitian berikut menghasilkan pengaruh yang signifikan dari status sosial ekonomi keluarga terhadap prestasi belajar siswa. (Chotimah, 2017) memperlihatkan bahwasanya status sosial ekonomi orang tua terdapat pengaruh signifikan terhadap prestasi belajar siswa. Menurut penelitian yang dilakukan (D. E. Pratiwi \& Prasetya, 2019) hasil penelitiannya menunjukkan ada pengaruh positif dan signifikan antara status sosial ekonomi dengan prestasi belajar siswa.

Menurut penelitian yang dilakukan oleh (Inayah, R.Martono, T.Sawiji, 2013) Hasil penelitian itu menyatakan bahwasanya fasilitas belajar mempengaruhi secara signifikan terhadap prestasi belajar siswa. Dalam penelitian (Wulandari, 2019) menunjukkan bahwa adanya pengaruh positif baik secara parsial ataupun simultan dengan adanya pemanfaatan fasilitas belajar terhadap prestasi belajar. Menurut penelitian (Cynthia, 2015) mengemukakan bahwasanya fasilitas belajar mempengaruhi secara signifikan terhadap prestasi belajar peserta didik. Dalam penelitian oleh (Dewi Yonita, 2014) berdasarkan hasil hipotesis $\mathrm{H}_{4}$ terdapat pengaruh fasilitas belajar terhadap prestasi belajar siswa, hasil analisis dalam penelitian berikut menyimpulkan adanya pengaruh positif antara fasilitas belajar terhadap prestasi belajar siswa. Adapun penelitian yang dilaksanakan oleh (Sunadi, 2010) mengemukakan bahwasanya pemanfaatan fasilitas belajar secara parsial tak mempengaruhi prestasi belajar.

Berdarsarkan permasalahan yang ditemukan dan penjelasan yang telah diuraikan di atas, adapun alasan peneliti untuk memilih tingkat pendidikan orang tua, pendapatan orang tua, semangat belajar dan fasilitas belajar. Pendidikan orang tua dapat mempengaruhi pola pikir orang tua dalam mendidik anaknya, bagaimana anaknya dapat memperoleh prestasi seperti kedua orang tua. Pendapatan orang tua memiliki keterkaitan dengan bagaimana orang tua dapat memenuhi kebutuhan belajar anaknya, seperti kebutuhan membeli buku dan membeli kuota internet. Semangat belajar yang tinggi dari dalam diri siswa juga membantu siswa untuk dapat memperoleh prestasi yang cemerlang, karena mereka memiliki semangat untuk meraih prestasi yang cemerlang. Dan juga fasilitas belajar seperti fasilitas buku, internet dan juga apakah yang terdapat disekolah dan apakah yang terdapat di rumah untuk menunjang prestasi siswa, maka dari uraian peneliti di atas, peneliti merumuskan paradigma penelitian mengenai kompensasi, semangat kerja, dan komunikasi berpengaruh terhadap kinerja karyawan, dinyatakan dalam hipotesis, tingkat pendidikan orang tua, pekerjaan orang tua, pendapatan orang tua, semangat belajar, minat belajar dan fasilitas belajar berpengaruh terhadap prestasi belajar.

\section{METODE PENELITIAN}

Penelitian berikut menerapkan metode asosiatif dengan pendekatan kuantitatif serta digunakannya analisis regresi linier berganda. Menurut (Sugiyono, 2016) Peneliti menggunakan strategi asosiatif untuk memperjelas keadaan sebab akibat dalam hubungan antara satu variabel dengan yang lain, dengan tujuan supaya sangat terlihat apakah ada pengaruh antara satu variabel dengan variabel yang lain. Peneliti memakai ujian kuantitatif dengan metode asosiatif yang ditujukan untuk melihat dampak tingkat sekolah dan gaji orangtua, energi untuk belajar, dan fasilitas pembelajaran terhadap prestasi siswa. 
Populasi ditentukan berdasarkan probability sampling berjenis random sampling dengan objek yang akan diteliti ditetapkan secara random tanpa melihat status pada populasi. Hal ini karena anggota populasi mempunyai karakter yang serupa atau homogen. Guna menentukan jumlah sampel, peneliti memakai sampling jenuh, dimana jumlah populasi yang akan dijadikan sampel penelitian. Kelas siswa pada SMK tamsis Mojokerto kelas X terbagi menjadi 3 kelas yakni X1 yang berjumlah 34 siswa/i, X2 yang berjumlah 34 siswa/i, dan X3 yang berjumlah 32 siswa/i. Peneliti mengambil populasi sebesar 100 siswa/i. Dengan demikian, probability sampling menggunakan sampling jenuh menghasilkan 100 siswa/i.

Pada penelitian berikut teknik yang dipakai pada pengumpulan data yakni Angket kuesioner, dokumentasi serta wawancara. Berdasarkan wawancara yang dilakukan oleh peneliti pada kelas SMK tamsis Mojokerto mendapatkan informasi bahwa proses pembelajaran yang diterapkan menggunakan metode ceramah, tanya jawab serta papan tulis sebagai sumber belajar dari sekolah yang nantinya digunakan juga oleh siswa. Maka siswa akan mudah bosan dalam berlangsungnya pembelajaran dikelas. Kelalaian siswa dalam memperhatikan materi berdampak pada rendahnya pemahaman, karena beberapa siswa menjadi pasif bahkan membuat gaduh di dalam kelas. Angket kuesioner yang diteliti oleh peneliti membahas dampak tingkat pendidikan serta pendapatan orang tua, semangat belajar terhadap prestasi belajar siswa pada SMK tamsis Mojokerto kelas X. Penelitian ini menggunakan skala likert sebagai penentuan skor pada instrumen penelitian mulai dari gradiasi negatif hingga positif berdasarkan nilai skronya yaitu 1,2,3,4,5. Tiap pertanyaan harus dijawab karena hasil dari jawaban pertanyaan akan dianalisa dengan SPSS versi 23.

Tabel 1 Indikator dan Penjelasan

\begin{tabular}{|c|c|c|}
\hline Variabel & Indikator & Penjelasan Indikator \\
\hline $\begin{array}{l}\text { Tingkat } \\
\text { Pendidikan } \\
\text { Orang tua }\left(\mathrm{X}_{1}\right)\end{array}$ & $\begin{array}{l}\text { 1. Tingkat pendidikan orang tua } \\
\text { terhadap anaknya. } \\
\text { 2. Kesadaran orang tua akan } \\
\text { pendidikan. } \\
\text { 3. Motivasi orang tua terhadap } \\
\text { anaknya terkait pendidikan. } \\
\text { 4. Cerminan orang tua terhadap } \\
\text { pendidikan anaknya. }\end{array}$ & $\begin{array}{l}\text { 1. Pendidikan orang tua memiliki } \\
\text { keterkaitan dengan pendidikan } \\
\text { anaknya. } \\
\text { 2. Sikap orang tua pada kesadaran } \\
\text { anak dalam pendidikannya. } \\
\text { 3. Orang tua memotivasi anaknya } \\
\text { untuk belajar sepanjang usia. } \\
\text { 4. Pendidikan orang tua tidak jauh dari } \\
\text { pendidikan anaknya. }\end{array}$ \\
\hline $\begin{array}{l}\text { Tingkat } \\
\text { Pendapatan } \\
\text { Orang tua }\left(\mathrm{X}_{2}\right)\end{array}$ & $\begin{array}{l}\text { 1. Pendapatan orang tua } \\
\text { memberikan fasilitas belajar } \\
\text { pada anaknya. } \\
\text { 2. Pendapatan orang tua } \\
\text { membuat anaknya nyaman } \\
\text { belajar. } \\
\text { 3. Pendapatan orang tua } \\
\text { membuat anaknya serba di } \\
\text { fasilitasi. }\end{array}$ & $\begin{array}{l}\text { 1. Pendapatan orang tua memberikan } \\
\text { yang terbaik untuk anaknya agar } \\
\text { dapat belajar. } \\
\text { 2. Pendapatan orang tua membuat } \\
\text { anaknya mudah untuk mendapatkan } \\
\text { apa yang mereka butuhkan. } \\
\text { 3. Pendapatan orang tua membantu } \\
\text { anaknya mudah mendapatkan } \\
\text { fasilitas yang ada untuk } \\
\text { pembelajaran. }\end{array}$ \\
\hline $\begin{array}{l}\text { Semangat } \\
\text { Belajar }\left(\mathrm{X}_{3}\right)\end{array}$ & $\begin{array}{l}\text { 1. Siswa dengan semangat } \\
\text { belajar yang tinggi membuat } \\
\text { prestasi siswa meningkat. } \\
\text { 2. Semangat belajar dalam } \\
\text { menjalani pembelajaran. } \\
\text { 3. Semangat belajar untuk dapat } \\
\text { menjadi orang yang berguna. } \\
\text { 4. Semangat belajar untuk }\end{array}$ & $\begin{array}{l}\text { 1. Semangat belajar terhadap prestasi } \\
\text { yang dihasilkan siswa. } \\
\text { 2. Semangat belajar siswa dalam } \\
\text { menjalani kegiatan pembelajaran. } \\
\text { 3. Semangat belajar untuk dapat menjadi } \\
\text { orang yang berguna suatu saat. } \\
\text { 4. Semangat belajar siswa untuk dapat } \\
\text { menjadi lebih baik. }\end{array}$ \\
\hline
\end{tabular}



Prestasi Belajar Siswa di Masa Pandemi - Mochammad Vecky al Zuhry, Muhammad Abdul Ghofur DOI: https://doi.org/10.31004/edukatif.v3i5.895

\begin{tabular}{lll}
\hline Variabel & \multicolumn{1}{c}{ Indikator } & Penjelasan Indikator \\
\hline & $\begin{array}{l}\text { mendapatkan prestasi belajar } \\
\text { yang tinggi. }\end{array}$
\end{tabular}

\begin{tabular}{lll}
\hline Fasilitas & 1. & Kuota gratis yang di fasilitasi \\
Belajar $\left(\mathrm{X}_{4}\right)$ & & pemerintah. \\
& 2. & Wifi penunjang pembelajaran. \\
& 3. & Alat elektronik seperti gadget \\
& yang canggih. \\
& 4. & Sinyal pada jaringan.
\end{tabular}

1. Penerapan kuota gratis terhadap pembelajaran siswa.

2. Wifi sebagai fasilitas pembelajaran .

3. Peralatan seperti komputer, laptop, dan hp sebagai penunjang pembelajaran .

4. Sinyal sebagai penunjang fasilitas pembelajaran

\begin{tabular}{|c|c|c|}
\hline $\begin{array}{l}\text { Prestasi } \\
\text { Belajar Siswa } \\
\text { (Y) }\end{array}$ & $\begin{array}{l}\text { 1. Nilai ujian tengah semester } \\
\text { ganjil yang dilaksanakan } \\
\text { tahun } 2020 \text {. } \\
\text { 2. Nilai ujian tengah semester } \\
\text { ganjil yang dilaksanakan }\end{array}$ & $\begin{array}{l}\text { 1. Untuk mengetahui apakah nilai } \\
\text { ujian tengah semester masing- } \\
\text { masing siswa/i mendapatkan } \\
\text { peningkatan atau tidak pada tahun } \\
\text { 2020. }\end{array}$ \\
\hline
\end{tabular}
tahun 2021.

3. Nilai ujian akhir semester ganjil yang dilaksanakan tahun 2020.

4. Nilai ujian akhir semester ganjil yang dilaksanakan tahun 2021.

2. Untuk mengetahui apakah nilai ujian tengah semester masingmasing siswa/i mendapatkan peningkatan atau tidak pada tahun 2021.

3. Untuk mengetahui apakah nilai ujian akhir semester masing-masing siswa/i mendapatkan peningkatan atau tidak pada tahun 2020 .

4. Untuk mengetahui apakah nilai ujian akhir semester masing-masing siswa/i mendapatkan peningkatan atau tidak pada tahun 2021.

Sumber: data primer yang diolah

\section{Skala Likert}

Berikut ini adalah lima tingkatan yang diukur dalam skala likert :

$$
\begin{aligned}
& 1=\text { Sangat Tidak Setuju (STS) } \\
& 2=\text { Tidak Setuju (TS) } \\
& 3=\text { Netral (N) } \\
& 4=\text { Setuju (S) } \\
& 5=\text { Sangat Setuju (SS) }
\end{aligned}
$$

Perolehan data yang dihasilkan dari skor 1 hingga 5 yang digunakan dalam pengukuran tanggapan pada variabel harga, produk, pemasaran dan keputusan pembelian, pada variabel yang ada dalam rentang interval kelas.

Tabel 2 Tolak Ukur Skala Likert

\begin{tabular}{ll}
\hline 1 & $:$ Sangat tidak setuju \\
\hline 2 & :Tidak setuju \\
\hline 3 & $:$ Netral \\
\hline 4 & $:$ Setuju \\
\hline 5 & $:$ Sangat Setuju \\
\hline
\end{tabular}




\section{Uji validitas}

Teknik pengolahan data menggunakan uji validitas serta uji reliabilitas. Uji validitas merupakan proses mengukur sejauh manakah alat ukur itu sendiri melakukan pengukuran akan hal yang akan dilakukan pengukurannya (Sugiyono, 2016). Uji validitas dalam penelitian ini, peneliti memanfaatkan korelasi person product moment melalui melakukan perbandingan akan $\mathrm{r}$ tabel dan $\mathrm{r}$ penghitungan. Peneliti melakukan uji validitas menerapkan uji dua sisi menggunakan tingkat kepentingan 5\% atau 0,05. Bila nilai $r$ hitung $>\mathrm{r}$ tabel, hal tersebut dikategorikan sebagai valid. Pertanyaan yang diajukan sebanyak 60 pertanyaan. Sedangkan strategi analisi data yang dilakukan oleh peneliti menunjukkan regresi linier sederhana dengan program SPSS varian 23. Berbagai uji linier merupakan model kondisi yang menggambarkan hubungan antara dua variabel bebas (X1) dan (X2) pada variabel terikat (Y).

\section{Uji reliabilitas}

Menurut Sugiyono (2016), reliabilitas yakni konsistensi sebuha instrumen guna melakukan pengukuran akan sebuah survei atau polling yang ialah penunjuk sebuah variabel ataupun peubah dimana alat estimasi yang digunakan valid dan tetap dapat diprediksi atau stabil jika estimasi tersebut dapat diulang setiap waktu. Metode uji reliabilitas polling atau angket di dalam penelitian berikut yakni menggunakan uji reliabilitas internal. Uji reliabilitas adalah uji yang dimanfaatkan guna menentukan konsistensi suatu alat penduga yang dipakai. Uji reliabilitas dilaksanakan melalui melakukan perhitungan akan nilai Cronbach Alpha adalah > 0.60 atau dapat juga juga dimungkinkan dengan menghitung nilai Cronbach Alpha > r tabel.

\section{Uji Asumsi Model Regresi}

1) Uji Normalitas

Distribusi data yang mengikuti ataupun mendekati distribusi normal bisa diketahui melalui melaksanakan uji normalitas. Metodologi parametrik digunakan untuk menyelidiki statistik apabila data berdistribus normal, sementara itu jika data tak mempunyai distribusi normal, metodologi non parametrik digunakan. Dalam penelitian berikut, metode uji Kolmogorov-Smirnov digunakan, yang merupakan uji normalitas yang terbanyak dipakai, apalagi sesudah kemajuan program statistik tersebar luas.

\section{2) Uji Multikolinearitas}

Berfungsi guna melakukan pengukuran agar derajat asosiasi (kedekatan) menggunakan ukuran korelasi (r) terhadap hubungan/dampak antar variabel bebas.

3) Uji Heteroskedastisitas

Heteroskedastisitas terjadi ketika muncul sebagai contoh standar pada titik scatterplot, baik menyempit, memanjang, atau bergelombang. Ketika titik pada scatterplot menyebar di sepanjang Y-pivot, dan bentuknya tak beraturan, pada saat itu variabel bebas yakni homoskedastisitas ataupun tak terjadi heteroskedastisitas.

4) Uji Autokorelasi

Uji autokorelasi digunakan guna suatu alasan, khususnya untuk memutuskan apakah ada hubungan antar individu dari suatu rangkaian data yang diperhatikan dan diselidiki oleh ruang atau waktu. Pengujian ini dimaksudkan untuk melihat apakah ada perubahan antara kesalahan penganggu di dalam periode $t$ dan kesalahan di dalam periode t-1 atau periode terdahulu (Sugiyono, 2016).

5) Uji Hipotesis

1) Uji F

Menurut Sugiyono (2016), uji F pada dasarnya menandakan apakah tiap variabel bebas yang dimasukkan ke dalam model mempengaruhi variabel terikat. Sebagai korelasi nilai, bandingkan F hitung dan $\mathrm{F}$ tabel dengan tingkat peluang pada alpha 0,05 . Jika nilai kepentingan di bawah 0,05 , variabel bebas secara simultan mempengaruhi variabel terikat. 
2507 Pengaruh Tingkat Pendidikan, Pendapatan Orang Tua, Semangat Belajar, dan Fasilitas Belajar terhadap Prestasi Belajar Siswa di Masa Pandemi - Mochammad Vecky al Zuhry, Muhammad Abdul Ghofur DOI: https://doi.org/10.31004/edukatif.v3i5.895

2) Uji t

Menurut Sugiyono (2016), uji statistik t digunakan untuk menguji pengaruh variabel terikat yang digunakan dalam memperjelas variabel bebas secara pasrsial. Untuk korelasi nilai, jika nilai di bawah 0,05 maka variabel bebas secara parsial mempengaruhi variabel terikat.

3) Uji Koefisien Determinasi

Menurut Sugiyono (2016), koefisien determinasi adalah pengukuran kapasitas model dalam mengklarifikasi keragaman variabel bebas (Y). Dalam koefisien determinasi, nilai koefisien bernilai 0 atu 1. Nilai koefisien determinasi menunjukkan kapasitas variabel yang bergantung dalam mengklarifikasi berbagai variael bebas sangat terbatas. Selain itu, nilai koefisien determinasi yang mendekati satu menyiratkan bahwa variabel terikat hampir memberikan semua data yang diharapkan untuk memperkirakan jumlah variabel bebas sangat terbatas.

\section{HASIL DAN PEMBAHASAN PENELITIAN}

\section{Gambaran Umum Objek Penelitian}

Mata pelajaran kelas X SMK tamsis Mojokerto, merupakan SMK yang beralamat di Jl. Panderman VIII, Mergelo, Wates, , Magersari, Kota Mojokerto, Jawa Timur 61317. Responden dalam penelitian ini merupakan siswa/i SMK tamsis Mojokerto kelas X yang berjumlah 100 siswa, yang kebanyakan dengan usia berkisar antara 15-17 tahun.

\section{Uji Validitas}

Data yang sudah diperoleh maka akan dianalisa menggunakan SPSS dengan outputnya :

Menurut Sugiyono (2016) sebuah tes dapat dikatakan memiliki validitas yang tinggi jika tes tersebut melakukan estimasi kapasitasnya, atau memberikan estimasi yang membawa pemahaman dengan signifikansi dan motivasi dari tes tersebut. Uji validitas diidentifikasi dengan tingkat kesamaan antara definisi konseptual dan operasional. Dikatakan valid apabila suatu instrumen dapat mengkuantifikasi apa yang diinginkan dan mengungkap data variabel yang terkonsentrasi secara tepat. Mengolah data dan dasar melalui SPSS23 bisa dikatakan valid. Terdapat 15 butir pertanyaan yang telah dicoba dan ditangani untuk menguji validitasnya dengan hasil yang valid. Data valid karena nilai signifikasinya kurang dari 0,05.

\section{Uji Reliabilitas}

Menurut Sugiyono (2016) mengungkapkan bahwa koefisien Alpha Cronbach suatu koefisien reliabilitas yang sering digunakan, dikarenakan bisa menggambarkan variasi dengan format item benar atau salah atau juga bukan. Jika nilai Alpha Cronbach lebih dari 0,6 maka variabel dikatakan reliabel.

Berdasarkan tabel tersebut menunjukkan hasil cronbach's alpha $>0,6$ maka instrumen riset dikatakan reliabel.

\section{Uji Asumsi Model Regresi}

\section{Uji Normalitas}

Tabel 3 Hasil Uji Normalitas

\begin{tabular}{lr}
\hline $\mathrm{N}$ & 100 \\
\hline Asymp. Sig. (2-tailed) & 0,212 \\
\hline
\end{tabular}

Menurut Sugiyono (2016) menyatakan bahwa uji normalitas untuk menguji normal tidaknya suatu data, dikatakan normal jika memberikan nilai sig $>0,05$. Berdasarkan pada hasil uji normalitas pada tabel 3, diketahui nilai signifikansi sebesar 0,212. Apabila nilainya $>0,05$ berarti nilai residual data teruji normal yang artinya model regresi termasuk model yang baik terdistribusi secara normal. 
2508 Pengaruh Tingkat Pendidikan, Pendapatan Orang Tua, Semangat Belajar, dan Fasilitas Belajar terhadap Prestasi Belajar Siswa di Masa Pandemi - Mochammad Vecky al Zuhry, Muhammad Abdul Ghofur DOI: https://doi.org/10.31004/edukatif.v3i5.895

\section{Uji Multikolinearitas}

Tabel 4 Hasil Uji Multikolinearitas

\begin{tabular}{lrr}
\hline Variabel & Tolerance & VIF \\
\hline Tingkat Pendidikan Orang Tua & 0,814 & 1,229 \\
\hline Tingkat Pendapatan Orang Tua & 0,700 & 1,429 \\
\hline Semangat Belajar & 0,677 & 1,476 \\
\hline Fasilitas Belajar & 0,736 & 1,360 \\
\hline
\end{tabular}

Uji Multikolinearitas mempunyai tujuan dalam menguji model regresi apakah terdapat korelasi antar variabel bebas. Apabila terjadinya korelasi, maka terdapat problem multikolinearitas Sugiyono (2016). Dari hasil uji multikolinieritas dengan program SPSS, hasil dari uji multikolinearitas dapat dijelaskan bahwa tidak terjadi multikolinearitas karena dapat dibuktikan bahwa nilai dari VIF variabel tingkat pendidikan orang tua 1,229 yang berarti $<10$, nilai dari VIF variabel tingkat pendapatan orang tua 1,429 yang berarti $<10$, nilai dari VIF variabel semangat belajar 1,476 yang berarti < 10, nilai dari VIF variabel fasilitas belajar 1,360 yang berarti $<10$. Jadi bisa dinyatakan jika tidak ada gejala multikolinearitas pada penelitian ini.

\section{Uji Heteroskedastisitas}

Tabel 5 Hasil Uji Heteroskedastisitas (Gletser)

\begin{tabular}{lr}
\hline Variabel & Nilai Signifikansi \\
\hline Tingkat Pendidikan Orang Tua & 0,758 \\
\hline Tingkat Pendapatan Orang Tua & 0,430 \\
\hline Semangat Belajar & 0,685 \\
\hline Fasilitas Belajar & 0,813 \\
\hline
\end{tabular}

Dari tabel di atas dihasilkan keseluruhan variabel bebas $(\mathrm{X})$ mempunyai nilai sig $>0,05$, maka persamaan regresi tidak disimpulkan bahwan bebas dari heteroskedastisitas, sehingga residual data terbebas dari masalah heteroskedastisitas yang artinya model regresi termasuk model yang baik atau dapat diandalkan.

\section{Uji Autokorelasi}

Tabel 6 Hasil Uji Autokorelasi

\begin{tabular}{lr}
\hline $\mathrm{N}$ & 100 \\
\hline Run-Test & 0,841 \\
\hline
\end{tabular}

Dari tabel diatas,bisa dilihat bahwa data yang diuji autokorelasi memperoleh nilai $R$ Run-Test bernilai 0,841. Yang artinya menandakan data yang digunakan tidak terdapat autokorelasi, sebab nilai Run-Test nya berada pada nilai diatas 0,05 .

Uji t

Tabel 7 Uji t

\begin{tabular}{lr}
\hline Variabel & Nilai Signifikansi \\
\hline Tingkat Pendidikan Orang Tua & 0,018 \\
\hline Tingkat Pendapatan Orang Tua & 0,659 \\
\hline Semangat Belajar & 0,011 \\
\hline Fasilitas Belajar & 0,193 \\
\hline
\end{tabular}


Uji t merupakan uji untuk secara parsial untuk menguji pengaruh atau tidaknya variabel X terhadap Y. Pada hasil uji $\mathrm{t}$ X1 nilai signifikansinya $0,018<0,05$ yang bisa diartikan jika hipotesis diterima, sehingga tingkat pendidikan orang tua dapat memberikan pengaruh secara signifikan pada prestasi belajar siswa. Hasil uji t pada X2 nilai signifikansinya 0,659>0,05 yang bisa diartikan jika hipotesis ditolak, maka tingkat pendapatan orang tua tidak berpengaruh terhadap prestasi belajar siswa, hasil uji t pada X3 nilai signifikansinya $0,011<0,05$ yang bisa diartikan jika hipotesis diterima, maka semangat belajar berpengaruh terhadap prestasi belajar siswa, hasil uji t pada X4 nilai signifikansinya 0,193>0,05 yang bisa diartikan jika hipotesis ditolak, maka fasilitas belajar tidak berpengaruh terhadap prestasi belajar siswa. Dapat disimpulkan bahwa secara parsial variabel X1 dan X3 memiliki pengaruh signifikan terhadap variabel Y.

\section{Uji F}

Tabel 8 Uji F

\begin{tabular}{lr}
\hline $\mathrm{N}$ & 100 \\
\hline Nilai Signifikansi & 0,046 \\
\hline
\end{tabular}

Pada hasil uji f menunjukkan bahwa $0,046<0,05$ yang dapat diartikan bahwa hasil perhitungan itu signifikan dan hipotesis diterima. Hal ini berarti variabel bebas yang terdiri dari tingkat pendidikan orang tua, tingkat pendapatan orang tua, semangat belajar, dan fasilitas belajar secara simultan mempunyai pengaruh signifikan terhadap variabel terikatnya yaitu prestasi belajar siswa.

\section{Koefisien Determinasi $\left(\mathbf{R}^{2}\right)$}

Tabel 9 Uji Koefisien Determinasi

\begin{tabular}{lr}
\hline $\mathrm{N}$ & 100 \\
\hline $\mathrm{R}$ & 0,310 \\
\hline $\mathrm{R}$ Square & 0,960 \\
\hline
\end{tabular}

Pada hasil nilai dari pengujian koefisien determinasi didasari pada kolom $\mathrm{R}$ square menunjukkan nilai 0,96. Yang dapat diartikan bahwa kontribusi variabel tingkat pendidikan orang tua, tingkat pendapatan orang tua, semangat kerja, dan fasilitas belajar terhadap variabel prestasi belajar siswa sejumlah $96 \%$. Dan yang tidak diteliti pada penelitian ini tersisa pengaruh variabel lain yaitu sejumlah $4 \%$.

\section{Pengaruh Tingkat Pendidikan Orang Tua (X1), terhadap Prestasi Belajar Siswa (Y)}

Tingkat pendidikan orang tua berpengaruh terhadap prestasi belajar siswa di SMK Tamsis Mojokerto kelas X. Dengan demikian, $\mathrm{H}_{1}$ yang menyatakan bahwa ada pengaruh antara tingkat pendidikan orang tua terhadap prestasi belajar siswa di SMK Tamsis Mojokerto kelas X adalah layak. Penelitian ini dikuatkan oleh Inayah \& Martono, (2018) yang menyatakan bahwa ada pengaruh antara tingkat pendidikan orangtua terhadap prestasi belajar siswa yang menempuh studi Pendidikan Guru di Universitas Jakarta. Terlebih lagi, penelitian sesuai Andri, (2020) yang mengungkapkan bahwa ada pengaruh antara tingkat sekolah orangtua terhadap prestasi belajar siswa yang belajar Ekonomi Guru di Universitas Sulawesi.

Penelitian ini diarahkan pada SMK Tamsis Mojokerto, dan menemukan perbedaan dengan penelitian terdahulu sebagai objek dan waktu penelitian. Peneliti menyimpulkan bahwa tingkat pendidikan orang tua mempengaruhi prestasi belajar siswa di SMK Tamsis Mojokerto kelas X. Sangat terlihat bahwa tingkat pendidikan orang tua meningkatkan prestasi belajar siswa, karena informasi tentang orangtua yang mereka dapatkan selama mereka yang masih muda akhirnya bisa menjadikan pengalaman dan pendekatan untuk mendidik anak-anak mereka menjadi lebih baik. Siswa dapat lebih mengembangkan prestasi belajar mereka karena pengaruh, dukungan, dan pengalaman orang tua mereka. 
2510 Pengaruh Tingkat Pendidikan, Pendapatan Orang Tua, Semangat Belajar, dan Fasilitas Belajar terhadap Prestasi Belajar Siswa di Masa Pandemi - Mochammad Vecky al Zuhry, Muhammad Abdul Ghofur DOI: https://doi.org/10.31004/edukatif.v3i5.895

\section{Pengaruh Tingkat Pendapatan Orang Tua (X2), Terhadap Prestasi Belajar Siswa (Y)}

Tingkat pendapatan orangtua tidak berpengaruh terhadap prestasi belajar siswa SMK Tamsis Mojokerto kelas X. Oleh karena itu, $\mathrm{H} 2$ yang menyatakan bahwa ada pengaruh antara tingkat gaji orang tua terhadap prestasi belajar siswa SMK Tamsis Mojokerto kelas X ditolak. Penelitian ini dikuatkan oleh Purnomo dan Rosalita, (2016) yang menyatakan bahwa tidak ada pengaruh antara tingkat gaji orangtua terhadap prestasi belajar siswa kelas dua belas SMA 2 Surakarta. Seperti pendalaman Rio, (2019) yang menyatakan bahwa tidak ada pengaruh antara tingkat gaji orang tua terhadap prestasi belajar mahasiswa Akuntansi di Universitas Trunojoyo.

Penelitian ini dilakukan di SMK tamsis Mojokerto, dan mendapatkan perbedaan dengan penelitian terdahulu berupa objek penelitian yang dilakukan serta tahun penelitian. Peneliti menyimpulkan bahwa tingkat pendapatan orang tua tidak berpengaruh terhadap prestasi belajar siswa SMK tamsis Mojokerto kelas X. Hal ini terlihat bahwa tingkat pendapatan orang tua tidak mempengaruhi prestasi belajar mereka, karena prestasi baik maupun prestasi yang buruk tidak ditentukan dari kekayaan orang tua, siswa dengan niat yang tinggi, rajin dan pantang menyerah akan dapat membuat mereka belajar dan memperoleh prestasi belajar yang baik.

\section{Pengaruh Semangat Belajar (X3), Terhadap Prestasi Belajar Siswa (Y)}

Semangat belajar berpengaruh terhadap prestasi belajar siswa SMK tamsis Mojokerto kelas X. Dengan demikian, $\mathrm{H}_{3}$ menyatakan adanya pengaruh antara semangat belajar terhadap prestasi belajar siswa SMK tamsis Mojokerto kelas X diterima. Penelitian ini didukung oleh Wahyuni, (2020) menyatakan adanya pengaruh yang antara semangat belajar terhadap prestasi belajar siswa kelas 11 SMK 1 Surakarta. Serta penelitian menurut Tias, (2019) yang menyatakan bahwa adanya pengaruh antara semangat belajar terhadap prestasi belajar mahasiswa jurusan Pertanian Universitas Diponegoro.

Penelitian ini dilakukan di SMK tamsis Mojokerto, dan mendapatkan perbedaan dengan penelitian terdahulu berupa objek penelitian yang dilakukan serta tahun penelitian. Peneliti menyimpulkan bahwa semangat belajar memberikan pengaruh terhadap prestasi belajar siswa SMK tamsis Mojokerto kelas X. Hal ini terlihat bahwa semangat belajar siswa SMK tamsis Mojokerto kelas X sangat lah tinggi, bisa dilihat dari cara mereka tetap belajar meskipun dalam masa pandemi namun mereka tetap belajar dan berusaha meraih prestasi belajar yang baik. jenis motivasi ini timbul karena ada ajakan, suruhan, atau paksaan dari orang lain sehingga semangat belajar siswa SMK tamsis Mojokerto kelas X mempengaruhi prestasi belajar siswa.

\section{Pengaruh Fasilitas Belajar (X4), Terhadap Prestasi Belajar Siswa (Y)}

Fasilitas belajar tidak memberikan pengaruh terhadap prestasi belajar siswa SMK tamsis Mojokerto kelas X. Dengan demikian, $\mathrm{H}_{4}$ yang menyatakan bahwa ada pengaruh antara fasilitas belajar terhadap prestasi belajar siswa SMK tamsis Mojokerto kelas X ditolak. Penelitian ini didukung oleh Wulandari, (2019) menyatakan tidak adanya pengaruh yang antara fasilitas belajar terhadap prestasi belajar siswa kelas 12 SMA 1 Jambi. Serta penelitian menurut Johan, (2018) yang menyatakan bahwa tidak adanya pengaruh antara fasilitas belajar terhadap prestasi belajar mahasiswa jurusan Manajemen Universitas Jember.

Penelitian ini dilakukan di SMK tamsis Mojokerto, dan mendapatkan perbedaan dengan penelitian terdahulu berupa objek penelitian yang dilakukan serta tahun penelitian. Peneliti menyimpulkan bahwa fasilitas belajar tidak memberikan pengaruh terhadap prestasi belajar siswa SMK tamsis Mojokerto kelas X. Hal ini terlihat bahwa fasilitas belajar tidak mempengaruhi prestasi belajar mereka, karena prestasi baik maupun prestasi yang buruk tidak ditentukan dari fasilitas belajar yang mereka miliki, siswa dengan niat yang tinggi, rajin dan pantang menyerah akan dapat membuat mereka belajar dan memperoleh prestasi belajar yang baik. 
2511 Pengaruh Tingkat Pendidikan, Pendapatan Orang Tua, Semangat Belajar, dan Fasilitas Belajar terhadap Prestasi Belajar Siswa di Masa Pandemi - Mochammad Vecky al Zuhry, Muhammad Abdul Ghofur DOI: https://doi.org/10.31004/edukatif.v3i5.895

\section{Pengaruh Tingkat Pendidikan Orang Tua (X1), Tingkat Pendapatan Orang Tua (X2), Semangat Belajar (X3), Dan Fasilitas Belajar (X4) Terhadap Prestasi Belajar Siswa (Y)}

Tingkat pendapatan orang tua, tingkat pendapatan orang tua, semangat belajar, dan fasilitas belajar secara simultan memberikan pengaruh terhadap prestasi belajar siswa SMK tamsis Mojokerto kelas X. Dengan demikian, $\mathrm{H}_{5}$ yang menyatakan bahwa ada pengaruh antara tingkat pendapatan orang tua, tingkat pendapatan orang tua, semangat belajar, dan fasilitas belajar terhadap prestasi belajar siswa SMK tamsis Mojokerto kelas X diterima. Penelitian ini didukung oleh Wirawan (2017), yang menyatakan bahwa adanya pengaruh yang antara pendapatan orang tua, tingkat pendapatan orang tua, semangat belajar, dan fasilitas belajar terhadap prestasi belajar siswa kelas 12 SMA 2 Kediri.

Peneliti menyimpulkan bahwa tingkat pendapatan orang tua, tingkat pendapatan orang tua, semangat belajar, dan fasilitas belajar memberikan pengaruh terhadap prestasi belajar siswa SMK tamsis Mojokerto kelas X. Hal ini terlihat bahwa tingkat pendapatan orang tua, tingkat pendapatan orang tua, semangat belajar, dan fasilitas belajar secara simultan mempengaruhi prestasi belajar mereka.

\section{KESIMPULAN}

Sesuai pembahasan dan hasil penelitian ini diperoleh kesimpulan bahwa tingkat pendapatan orang tua, berdampak signifikan pada prestasi belajar siswa. Tingkat pendidikan orang tua, tidak berpengaruh terhadap prestasi belajar siswa. Semangat belajar berdampak signifikan pada prestasi belajar siswa. Fasilitas belajar tidak berdampak pada prestasi belajar siswa. Dan tingkat pendapatan orang tua, pendidikan orang tua, semangat belajar, dan fasilitas belajar secara simultan berpengaruh terhadap prestasi belajar siswa.

Pembelajarn siswa SMK tamsis Mojokerto kelas X sudah cukup baik, dan hal yang perlu diperhatikan adalah fasilitas belajar, karena sekolah tidak memfasilitasi hp untuk setiap siswa, jadi diharapkan orang tua dapat memfasilitasi proses pembelajaran anaknya, sehingga dapat mencapai prestasi belajar yang baik.

\section{DAFTAR PUSTAKA}

Andi, N. (2014). Pengaruh Cara Belajar, Lingkungan Keluarga, Dan Fasilitas Belajar Terhadap Prestasi Belajar Ekonomi Akuntansi Siswa Kelas Xi Ips Sma Negeri 4 Magelang Tahun Ajaran 2013/2014. Economic Education Analysis Journal, 3(2), 241-248.

Andri, W. (2020). Pengaruh Pendidikan Orang Tua, Dan Fasilitas Belajar Terhadap Prestasi Belajar Ekonomi Guru Universitas Sulawesi. Economic Journal, 15(1), 105-116.

Chotimah, L. N., Ani, H. M., \& Widodo, J. (2017). Pengaruh Status Sosial Ekonomi Orang Tua Terhadap Pestasi Belajar Siswa (Studi Kasus Siswa Kelas Viii Smp Negeri 1 Jember Tahun Ajaran 2016/2017). Jurnal Pendidikan Ekonomi: Jurnal Ilmiah Ilmu Pendidikan, Ilmu Ekonomi Dan Ilmu Sosial, 11(1), 75. Https://Doi.Org/10.19184/Jpe.V11i1.5004

Cynthia, L. C., Martono, T., \& Indriayu, M. (2015). Pengaruh Fasilitas Belajar Dan Motivasi Belajar Terhadap Prestasi Belajar Mata Pelajaran Ekonomi Siswa Kelas Xi Iis Di Sma Negeri 5 Surakarta Tahun Ajaran 2015/2016. Jurnal Pendidikan Bisnis Dan Ekonomi, 01(02), 1-20. Http://Jurnal.Fkip.Uns.Ac.Id/Index.Php/Ptn/Article/View/7397/5169

Ghozali, I. (2016). Metode Penelitian Kuantitatif, Kualitatif, Dan R\&D. Jakarta: Erlangga.

Inayah, R., Martono, T., Sawiji, H. (2013). Pengaruh Kompetensi Guru, Motivasi Belajar Siswa, Dan Fasilitas Belajar Terhadap Prestasi Belajar Mata Pelajaran Ekonomi Pada Siswa Kelas Xi Ips Sma Negeri 1. In Jurnal Pendidikan Insan Mandiri (Vol. 1, Issue 1, Pp. 1-13). Http://Jurnal.Fkip.Uns.Ac.Id/Index.Php/S2ekonomi/Article/View/1899.

Johan. (2018). Pengaruh Fasilitas Belajar , Lingkungan, Dan Perhatian Orang Tua Terhadap Hasil Belajar 
2512 Pengaruh Tingkat Pendidikan, Pendapatan Orang Tua, Semangat Belajar, dan Fasilitas Belajar terhadap Prestasi Belajar Siswa di Masa Pandemi - Mochammad Vecky al Zuhry, Muhammad Abdul Ghofur DOI: https://doi.org/10.31004/edukatif.v3i5.895

Mahasiswa Manajemen Universitas Jember. Jurnal Manajemen, 5(1), 45-60.

Manginsihi, O., Yunus, H., \& Mopangga, H. (2013). Pengaruh Status Sosial Ekonomi Keluarga Terhadap Prestasi Belajar Siswa Kelas X Di Smk Negeri 4 Gorontalo. Skripsi, 15. Pendidikan, S., Fakultas, E., Universitas, E., \& Surabaya, N. (2020). Jurusan Pendidikan Ekonomi Universitas Negeri Surabaya Fathur Rahman Khoirurroziqin Abstrak Pengaruh Sosial Ekonomi Orang Tua Terhadap Indeks Prestasi Mahasiswa .... 08, 80-85.

Pratiwi, D. E., \& Prasetya, N. E. (2019). Pengaruh Status Sosial Ekonomi Dan Motivasi Belajar Terhadap Prestasi Belajar Siswa Kelas V Sdn Tambaksari I Surabaya. Jppguseda | Jurnal Pendidikan \& Pengajaran Guru Sekolah Dasar, 2(1), 36-40. Https://Doi.Org/10.33751/Jppguseda.V2i1.993

Pratiwi, E. W. (2020). Dampak Covid-19 Terhadap Kegiatan Pembelajaran Online Di Sebuah Perguruan Tinggi Kristen Di Indonesia Ericha Windhiyana Pratiwi Universitas Kristen Satya Wacana The Impact Of Covid-19 On Online Learning Activities Of A. Perspektif Ilmu Pendidikan, 34(1), 1-8.

Prihatin, M. S. (2016). Pengaruh Fasilitas Belajar, Gaya Belajar Danminat Belajar Terhadap Hasil Belajarmata Pelajaran Ekonomi Siswa. Fakultas Ekonomi Universitas Negeri Yogyakarta.

Purnomo, B., \& Rosalina, A. (2016). Pengaruh Status Sosial Ekonomi Orang Tua Terhadap Prestasi Belajar Siswa Kelas Ivb Sd No 64/1 Muara Bulian. Jurnal Gentala Pendidikan Dasar, 1(2), 275-297. Https://Doi.Org/10.22437/Gentala.V1i2.7120.

Rio, A. (2019). Pengaruh Pendapatan Orang Tua, Dan Semangat Belajar Terhadap Hasil Prestasi Mahasiswa Akuntansi Universitas Trunojoyo. Accounting Journal, 10(3), 15-40.

Sugiyono. (2016). Metode Penelitian, Dan R\&D. Bandung: Alfabeta.

Sugiyono. (2019). Metode Penelitian Kuantitatif, Kualitatif, Dan R\&D. Bandung: Alfabeta.

Sunadi, L. (2010). Pengaruh Motivasi Belajar Dan Pemanfaatan Fasilitas Belajar Terhadap Prestasi Belajar Siswa Pada Mata Pelajaran Ekonomi Kelas Xi Ips Di Sma Muhammadiyah 2 Surabaya. Jurnal Pendidikan Ekonomi, 1-19.

Tias, I. (2019). Pengaruh Semangat Belajar, Lingkungan, Dan Dorongan Orang Tua Terhadap Prestasi Mahasiswa Pertanian Universitas Diponegoro. Jurnal Pertanian, 8(4), 55-71.

Wahyuni, S. R. I., Keguruan, F., Ilmu, D. A. N., \& Maret, U. S. (2011). Hubungan Status Sosial Ekonomi Orang Tua Dan Pemanfaatan Media Belajar Dengan Prestasi Belajar Pada Siswa Kelas Xi Sma Batik 2 Surakarta Tahun Ajaran 2010/2011.

Wirawan, Y. R. (2017). Pengaruh Status Sosial Ekonomi Orang Tua Terhadap Prestasi Belajar Ekonomi Dan Perilaku Konsumsi Siswa. Jurnal Ekonomi Pendidikan Dan Kewirausahaan, 3(2), 147. Https://Doi.Org/10.26740/Jepk.V3n2.P147-167

Wulandari, E. T. (2019). Pentingnya Pengaruh Fasilitas Belajar Terhadap Prestasi Belajar Siswa The Importance Of The Effect Of Learning Facilities On Student Learning Achievement. Eprosiding Seminar Nasional Biologi Vi, 20, 258-261. 